\title{
An evaluation of circulating activated TAFI in septic DIC: a case series and review of the literature
}

Takaaki Totoki ${ }^{1,2,3^{*}}$, Takashi Ito ${ }^{2,3}$, Midori Kakuuchi ${ }^{2}$, Nozomi Yashima ${ }^{2}$, Ikuro Maruyama ${ }^{3}$ and Yasuyuki Kakihana ${ }^{2}$

\begin{abstract}
Background: Administration of recombinant human soluble thrombomodulin (rTM) is often used in Japan to treat septic disseminated intravascular coagulation (DIC). Thrombin-activatable fibrinolysis inhibitor (TAFI) is a fibrinolysis inhibitor activated by the thrombin-thrombomodulin complex, however, it is unknown whether circulating activated TAFI is increased after rTM administration in patients with DIC. Furthermore, the relationship between TAFI activation and the prognosis of septic DIC is not defined yet.

Case presentation: We report a series of 8 patient's TAFI activation with septic DIC treated by rTM. We sought to investigate the effect of rTM on TAFI activation and the association of plasma activated TAFI (TAFla/ai) levels with the prognosis of septic DIC.

Using plasma samples from clinical studies conducted from May 2016-March 2017 on eight patients with septic DIC at Kagoshima University Hospital, we measured plasma levels of total TAFI, TAFla/ai, thrombin-antithrombin complex (TAT), prothrombin fragment $1+2(F 1+2)$, soluble fibrin (SF), antithrombin (AT), protein $C(P C)$, protein $S(P S)$, and plasminogen activator inhibitor-1 (PAI-1) before and after intravenous rTM administration. Then, we evaluated the relationship of these marker levels to prognosis. The thrombin-rTM complex activated TAFI in vitro in plasma from a healthy volunteer. However, TAFla/ai levels did not significantly increase over baseline in the septic DIC patients after intravenous rTM administration. Baseline TAFla/ai levels in non-survivors were significantly higher than those in survivors.
\end{abstract}

Conclusions: Plasma TAFla/ai did not increase with rTM administration. Elevated baseline TAFla/ai concentration may be a negative prognostic indicator in septic DIC. Larger studies are needed to confirm the in vivo effect of rTM on TAFI activation.

Keywords: Disseminated intravascular coagulation, Thrombin-activatable fibrinolysis inhibitor, Sepsis, Thrombomodulin

\footnotetext{
* Correspondence: ttktkak@gmail.com

'Department of Anesthesiology \& Critical Care Medicine, Kyushu University,

Fukuoka, Japan

${ }^{2}$ Department of Emergency and Intensive Care Medicine, Kagoshima

University Graduate School of Medical and Dental Sciences, Kagoshima,

Japan

Full list of author information is available at the end of the article
}

(C) The Author(s). 2022 Open Access This article is licensed under a Creative Commons Attribution 4.0 International License, which permits use, sharing, adaptation, distribution and reproduction in any medium or format, as long as you give appropriate credit to the original author(s) and the source, provide a link to the Creative Commons licence, and indicate if changes were made. The images or other third party material in this article are included in the article's Creative Commons licence, unless indicated otherwise in a credit line to the material. If material is not included in the article's Creative Commons licence and your intended use is not permitted by statutory regulation or exceeds the permitted use, you will need to obtain permission directly from the copyright holder. To view a copy of this licence, visit http://creativecommons.org/licenses/by/4.0/ The Creative Commons Public Domain Dedication waiver (http://creativecommons.org/publicdomain/zero/1.0/) applies to the data made available in this article, unless otherwise stated in a credit line to the data. 


\section{Introduction}

Thrombin-activatable fibrinolysis inhibitor (TAFI) is synthesized and secreted by the liver [1]. TAFI can be activated by thrombin, and this reaction is markedly promoted by thrombomodulin, an anticoagulant protein expressed on the surface of endothelial cells [2]. During fibrinolysis, plasmin partially hydrolyzes fibrin, and plasminogen, plasmin, and tissue-type plasminogen activator (tPA) bind to the $\mathrm{C}$ terminal lysine residue generated in partially-hydrolyzed fibrin. Activated TAFI inhibits the binding of plasminogen, plasmin, and tPA by selectively excising the lysine residue at the $\mathrm{C}$-terminal of fibrin, thereby suppressing the fibrinolytic reaction and controlling the rate of fibrinolysis [3-5].

In sepsis, the expression of endothelial anticoagulant proteins, including thrombomodulin, is suppressed by endothelial damage. The decrease in thrombomodulin expression in the endothelium results in a hypercoagulable state and sepsis-associated disseminated intravascular coagulation (DIC) [6]. In Japan, recombinant human soluble thrombomodulin (rTM) is commonly used in expectation of activated protein $\mathrm{C}$ (APC)-dependent anticoagulant effects to counteract the hypercoagulable state in septic DIC [7]. Theoretically, administration of rTM may not only promote thrombin-mediated protein $\mathrm{C}$ activation but also promote thrombin-mediated TAFI activation, however, activated TAFI levels after rTM administration is unknown. Furthermore, the relationship between TAFI activation and the prognosis of septic DIC is not defined yet. In this study, we analyzed activated TAFI levels after rTM administration in patients with septic DIC.

The activated TAFI levels in no-survivors tended to be higher than in survivors.

\section{Case presentation}

We have treated eight patients with septic DIC in our prior research on activated protein $\mathrm{C}$ conducted May 2016-March 2017 in Kagoshima University Hospital [8].

The study was conducted using their plasma samples. This prospective observational study conformed to the provisions of the Declaration of Helsinki and was approved by the Ethics Committee of Kagoshima University Hospital. Between May 2016-March 2017, written informed consent was obtained from eight patients with sepsis-associated DIC prior to participation.

The diagnosis of sepsis and DIC was made according to the Third International Consensus Definition for Sepsis (Sepsis-3) [9] and the diagnostic criteria established by the Japanese Association for Acute Medicine (JAAM DIC criteria) [10], respectively.

\section{Sample preparation for TAFI assays}

Plasma from a healthy volunteer was incubated for $10 \mathrm{~min}$ at $37^{\circ} \mathrm{C}$ with varying concentrations of human thrombin (Sigma-Aldrich, St. Louis, MO, USA) and rTM (Asahi Kasei Pharma, Tokyo, Japan). The reaction was terminated by addition of a protease inhibitor cocktail containing hirudin (Sekisui Medical, Tokyo, Japan). The samples were centrifuged at $4{ }^{\circ} \mathrm{C}$ and the supernatants were stored at $80^{\circ} \mathrm{C}$ until analysis of TAFI concentrations.

Blood samples collected from the eight patients with sepsis-associated DIC before and after administration of rTM (Asahi Kasei Pharma, Tokyo, Japan), (130 or 380 $\mathrm{U} / \mathrm{kg}$, depending on renal function) via intravenous drip infusion on day 1 and day 2 were immediately anticoagulated with a one-tenth volume of sodium citrate and kept at $4{ }^{\circ} \mathrm{C}$. The samples were then centrifuged at $2000 \times \mathrm{g}$ for $10 \mathrm{~min}$ at $4{ }^{\circ} \mathrm{C}$ and plasma samples were stored at $-80^{\circ} \mathrm{C}$ until analysis of TAFI concentrations.

\section{Measurement of plasma levels of total TAFI, activated TAFI, TAT, F1 + 2, SF, AT, PC, PS, sTM, and PAI-1}

Plasma total TAFI levels were analyzed by the Imuclone Total TAFI ELISA (Sekisui Diagnostics, Stamford CT, USA). Plasma activated TAFI levels (TAFIa/ai) were analyzed by the Asserachrom TAFIa/TAFIai (Diagnostica Stago, Seine, France). Plasma thrombin-antithrombin complex (TAT) levels were analyzed using Stacia chemiluminescence enzyme immunoassay (CLEIA) TAT (LSI Medience, Tokyo, Japan). Plasma prothrombin fragment $1+2(\mathrm{~F} 1+2)$ levels were analyzed using Enzygnost $\mathrm{F} 1+2$ (Siemens Healthcare Diagnostics, Tokyo, Japan). Plasma soluble fibrin (SF) levels were analyzed using Iatro SF II (LSI Medience). Antithrombin (AT) was analyzed by a synthetic chromogenic substrate method using HemosIL ATLQ (Instrumentation Laboratory, Bedford MA, USA). Plasma protein C (PC) levels were measured by a synthetic chromogenic substrate method using HemosIL Protein C (Instrumentation Laboratory). Plasma protein S (PS) levels were measured by a synthetic chromogenic substrate method using HemosIL PS clot (Instrumentation Laboratory). Plasminogen activator inhibitor-1 (PAI-1) was analyzed using an LPIA - tPAI test (LSI Medience). All of the preceding assays were performed according to the manufacturers' instructions.

\section{Discussion and conclusions}

We examined the plasma levels of total TAFI, TAFIa/ai, $\mathrm{F} 1+2$, SF, AT, PS, and PAI-1 in eight patients with sepsis-associated DIC before and after administration of rTM over 2 days (Fig. 1).

The background characteristics of the eight patients are shown in Supplementary Table 1. Plasma soluble TM levels rapidly increased during a 30-60-min period of rTM administration $(380 \mathrm{U} / \mathrm{kg}$ except for cases \#3 

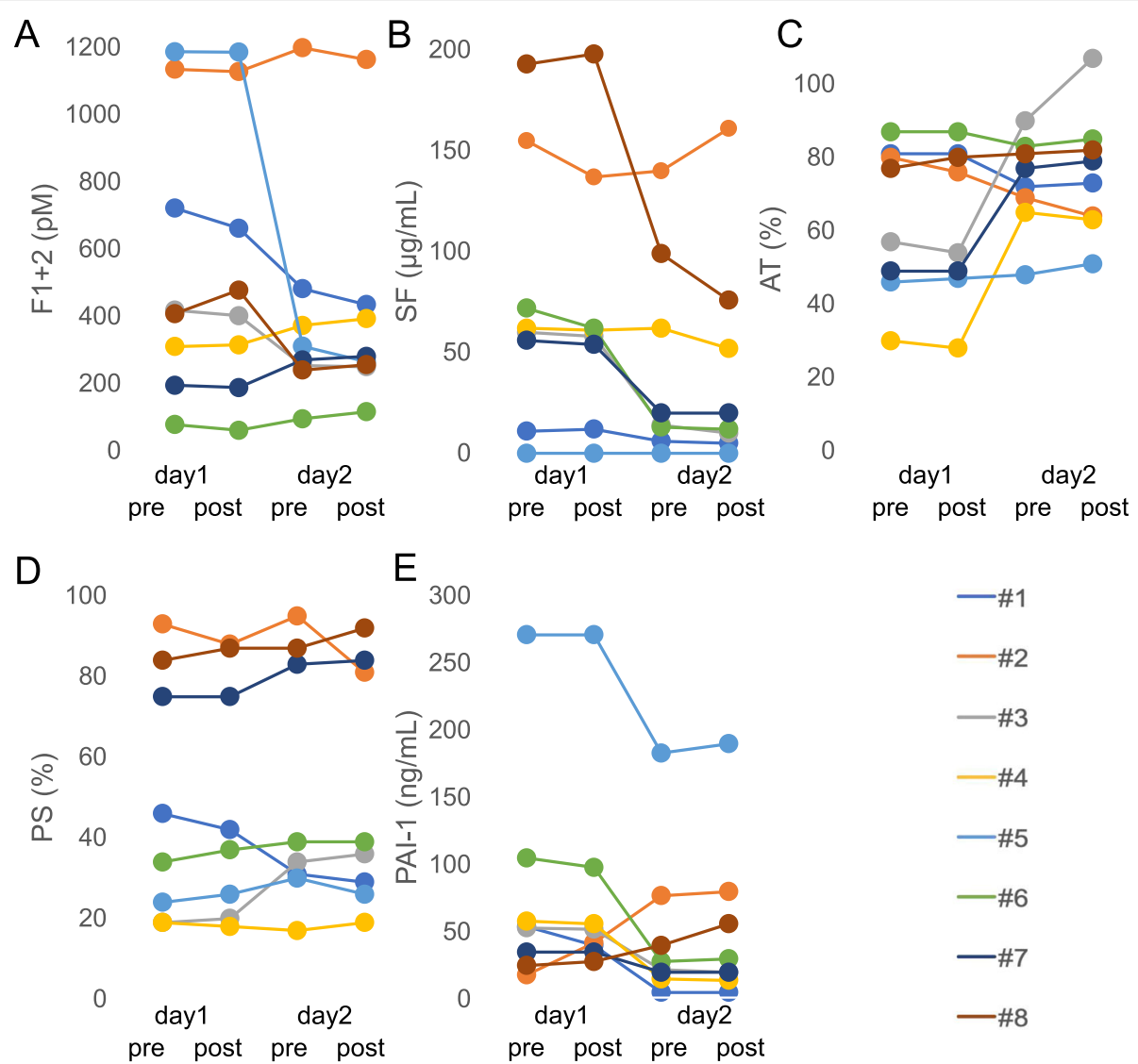

$E_{300}$
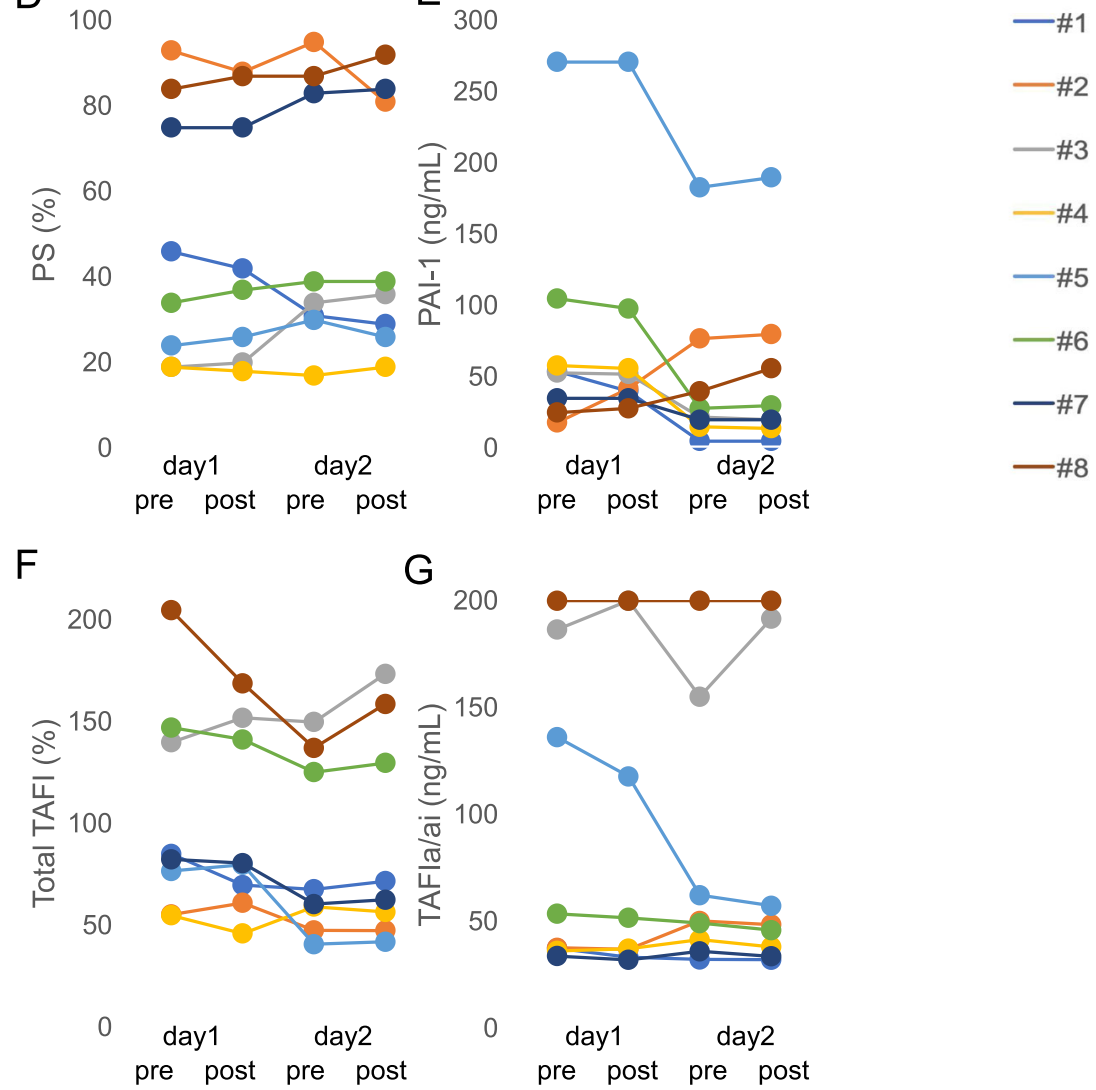

$\mathrm{G}_{200}$
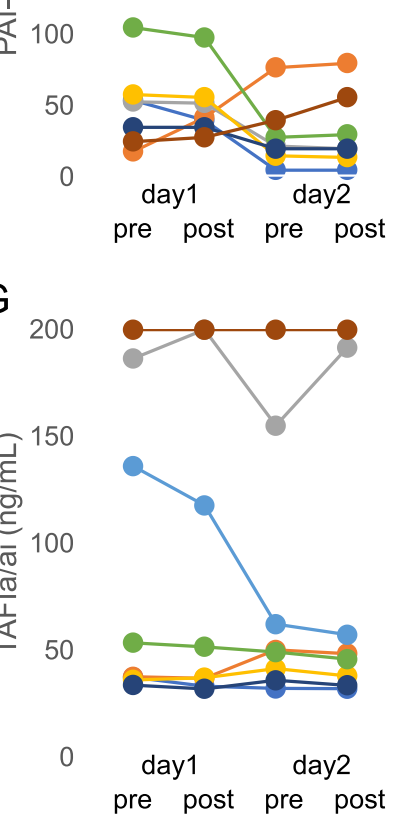

Fig. 1 Changes in coagulation/fibrinolysis markers in patients with sepsis-associated DIC before and after rTM administration. Blood samples were collected from the eight patients with sepsis-associated DIC before and after administration of rTM on day 1 and day 2. (A) Prothrombin fragment $1+2$ (F1 +2 ), (B) soluble fibrin (SF), (C) antithrombin (AT), (D) protein S (PS), (E) plasminogen activator inhibitor-1 (PAl-1), (F) total thrombin-activatable fibrinolysis inhibitor (TAFI), and (F) activated TAFI (TAFla/ai) levels were analyzed according to the manufacturers' instructions. TAFla/ai levels were not increased after rTM treatment except for the case \#3 and \#8. In the case of \#8, TAFla/ai levels at any points were higher than $200 \mathrm{ng} / \mathrm{mL}$, the upper limit of this measurement, however, the absorbance values were increased after rTM treatment from 2.19 to 2.32 on day 1, and from 2.48 to 2.62 on day 2

and \#5) to reach around $1 \mu \mathrm{g} / \mathrm{mL}[8]$. In these conditions, plasma TAFIa/ai levels were not increased after rTM treatment except for the cases \#3 and \#8.

In this study, we found that thrombin-rTM did not promoted increase plasma TAFIa/ai levels in most patients with sepsis-associated DIC. Three (\#3, \#6, and \#8) out of eight patients showed high total TAFI levels before rTM administration, and two (\#3 and \#8) out of the three patients showed high thrombin generation as evidenced by high $\mathrm{F} 1+2$ values. TAFIa/ai levels were increased in these two patients (\#3 and \#8) after rTM administration, suggesting that TAFIa/ai levels could be 
increased after rTM administration in patients with high total TAFI levels and high thrombin generation. However, this hypothesis is based on the data of eight patients, and thus larger scale analysis is necessary to confirm it.

Extensive activation of TAFI has been reported as an independent predictor of mortality in sepsis [11]. Our findings support this hypothesis in patients with sepsisassociated DIC. Increased TAFIa/ai may cause ischemic organ failure by inhibiting intravascular fibrinolysis. Increased TAFIa/ai may be the result of increased thrombin generation, which is also thought to be associated with ischemic organ failure and poor outcome. So, extensive activation of TAFI may be the cause or the result of critically ill conditions. In the latter case, rTM administration can improve outcome by suppressing thrombin generation. In the former case, rTM administration may not worsen outcome because rTM administration did not increase activated TAFI levels in most cases. However, it should be noted that activated TAFI levels can be increased after administration of rTM if baseline levels of total TAFI and thrombin generation are simultaneously elevated. Previous studies showed that inhibition or knockout of TAFI alleviated sepsis-induced organ injury in mice $[12,13]$, indicating that increased TAFIa/ai may account at least in part for sepsis-induced organ failure.

Plasma TAFIa/ai did not increase with rTM administration. The activated TAFI levels in no-survivors tended to be higher than in survivors. Therefore elevated baseline TAFIa/ai concentration may be a negative prognostic indicator in septic DIC. Larger studies are needed to confirm the in vivo effect of rTM on TAFI activation.

\section{Abbreviations}

AT: antithrombin; DIC: Disseminated intravascular coagulation; ELISA: Enzyme-linked immunosorbent assay; FDP: Fibrin/fibrinogen degradation products; F1 + 2: Prothrombin fragment $1+2$; PAI1: plasminogen activator inhibitor-1; rTM: Recombinant human soluble thrombomodulin; SF: soluble fibrin; sTM: soluble thrombomodulin; TAFI: thrombin-activatable fibrinolysis inhibitor; TAFla: Activated thrombin activatable fibrinolysis Inhibitor; TAT: Thrombin-antithrombin complex

\section{Acknowledgments}

The authors thank G. Honda (Asahi Kasei Pharma) for their expert technical assistance. We also wish to acknowledge the contribution of Dr. K. Yanagimoto for supporting patient enrollment. We thank Libby Cone, MD, MA, from DMC Corp. (www.dmed.co.jp <http://www.dmed.co.jp/>) for editing drafts of this manuscript.

\section{Authors' contributions}

TT contributed to data analysis. TI contributed to study design and manuscript preparation. MK and NY contributed to in vitro experiments. IM and YK contributed to data analysis and manuscript editing. All authors read and approved the final manuscript.

\section{Funding}

This study was supported by Asahi Kasei Pharma.
Availability of data and materials

The datasets used and/or analyzed during the current study are available from the corresponding author on reasonable request.

\section{Declarations}

\section{Ethics approval and consent to participate}

This study was approved by the Ethics Committee of Kagoshima University Hospital. Written informed consent was obtained from all patients prior to participation in the study.

\section{Consent for publication}

Not applicable.

\section{Competing interests}

IM and TI have received research funding from Asahi Kasei Pharma. All other authors state that they have no conflict of interests.

\section{Author details}

${ }^{1}$ Department of Anesthesiology \& Critical Care Medicine, Kyushu University, Fukuoka, Japan. ${ }^{2}$ Department of Emergency and Intensive Care Medicine, Kagoshima University Graduate School of Medical and Dental Sciences, Kagoshima, Japan. ${ }^{3}$ Department of Systems Biology in Thromboregulation, Kagoshima University Graduate School of Medical and Dental Sciences, Kagoshima, Japan.

Received: 27 October 2021 Accepted: 28 December 2021 Published online: 07 February 2022

\section{References}

1. Akinci B. Role of thrombin activatable fibrinolysis inhibitor in endocrine and cardiovascular disorders: an update. Recent Pat Endocr Metab Immune Drug Discov. 2012;6(3):210-7. https://doi.org/10.2174/187221412802481748.

2. Ito T, Kakihana Y, Maruyama I. Thrombomodulin as an intravascular safeguard against inflammatory and thrombotic diseases. Expert Opin Ther Targets. 2016;20(2):151-8. https://doi.org/10.1517/14728222.2016.1086750.

3. Esmon CT. The regulation of natural anticoagulant pathways. Scie Am Assoc Adv Sci. 1985;235(4794):1348-52. https://doi.org/10.1126/science.3029867.

4. Wenzel J, Assmann JC, Schwaninger M. Thrombomodulin-a new target for treating stroke at the crossroad of coagulation and inflammation. Curr Med Chem. 2014;21(18):2025-34. https://doi.org/10.2174/09298673216661312282 04839.

5. Bouma BN, Mosnier LO. Thrombin activatable fibrinolysis inhibitor (TAFI) — how does thrombin regulate fibrinolysis? Ann Med. 2006;38(6):37888. https://doi.org/10.1080/07853890600852898.

6. Faust SN, Levin M, Harrison OB, Goldin RD, Lockhart MS, Kondaveeti S, et al. Dysfunction of endothelial protein $C$ activation in severe meningococcal sepsis. N Engl J Med. 2001;345(6):408-16. https://doi.org/10.1056/nejm2001 08093450603.

7. Hayakawa M, Yamakawa K, Saito S, Uchino S, Kudo D, lizuka Y, et al. Recombinant human soluble thrombomodulin and mortality in sepsisinduced disseminated intravascular coagulation. A multicentre retrospective study. Thromb Haemost. 2016;115(6):1157-66. https://doi.org/10.1160/th1 5-12-0987.

8. Arishima T, Ito T, Yasuda T, Yashima N, Furubeppu H, Kamikokuryo C, et al, Circulating activated protein $C$ levels are not increased in septic patients treated with recombinant human soluble thrombomodulin. Thromb J. 2018; 28(16):1-7. https://doi.org/10.1186/s12959-018-0178-0.

9. Singer M, Deutschman CS, Seymour CW, Shankar-Hari M, Annane D, Bauer M, et al. The third international consensus definitions for Sepsis and septic shock (Sepsis-3). JAMA. 2016:315(8):801-2. https://doi.org/10.1001/jama.2016.0287.

10. Gando S, Iba T, Eguchi Y, Ohtomo Y, Okamoto K, Koseki K, et al. A multicenter, prospective validation of disseminated intravascular coagulation diagnostic criteria for critically ill patients: comparing current criteria. Crit Care Med. 2006;34(3):625-31. https://doi.org/10.1097/01.ccm. 0000202209.42491.38.

11. Semeraro F, Colucci M, Caironi P, Masson S, Ammollo CT, Teli R, et al. Platelet drop and fibrinolytic shutdown in patients with Sepsis. Crit Care Med. 2018;46(3):e221-8. https://doi.org/10.1097/ccm.0000000000002919.

12. Renckens R, Roelofs JJTH, ter Horst SAJ, van 't Veer C, Havik SR, Florquin S, et al. Absence of thrombin-activatable fibrinolysis inhibitor protects against 
sepsis-induced liver injury in mice. J Immunol. 2005;175(10):6764-71. https:// doi.org/10.4049/jimmunol.175.10.6764.

13. Muto Y, Suzuki K, lida H, Sakakibara S, Kato E, Itoh F, et al. EF6265, a novel inhibitor of activated thrombin-activatable fibrinolysis inhibitor, protects against sepsis-induced organ dysfunction in rats. Crit Care Med. 2009;37(5): 1744-9. https://doi.org/10.1097/ccm.0b013e31819ffc14.

\section{Publisher's Note}

Springer Nature remains neutral with regard to jurisdictional claims in published maps and institutional affiliations.

Ready to submit your research? Choose BMC and benefit from:

- fast, convenient online submission

- thorough peer review by experienced researchers in your field

- rapid publication on acceptance

- support for research data, including large and complex data types

- gold Open Access which fosters wider collaboration and increased citations

- maximum visibility for your research: over $100 \mathrm{M}$ website views per year

At BMC, research is always in progress.

Learn more biomedcentral.com/submissions 